\title{
Memories in Public Speaking Performance Anxiety \\ Reconstructed: A Qualitative Exploration Using Imagery Rescripting
}

\author{
K.S.F.M. Hermans \\ Faculty of Health, Medicine and Life Sciences \\ ksfm.hermans@student.maastrichtuniversity.nl
}

\begin{abstract}
Prior research on social anxiety disorder (SAD) has demonstrated the importance of anxiety provoking images which can be related to memories. Furthermore, by targeting the scope and meaning of these images, imagery rescripting (ImRs) has been proven to be effective. The present study examines how imagery plays a role in young adults' public speaking anxiety, a specifier of SAD. This is studied by reconstructing memories in adolescence conducted through ImRs. It was aimed to look for memories that provoked anxiety responses similar to the current anxiety and study them in terms of etiological factors. With regard to etiology, influence of negative teacher behavior was reported. The present results therefore suggest the factor teacher behavior as additional factor to Rapee and Spence's model on SAD when describing the development of public speaking performance anxiety. Furthermore, the results provide indications that ImRs could be effective for the specific anxiety group also. The focus should then be on negative teacher behavior as contributing to the anxiety. Finally, future research could examine whether a cognitive session preceding the ImRs will improve the effect of the intervention. This is considered as the time frame between the memory and the intervention is short and the young adult could still be vulnerable to teacher influence. Cognitively challenging encapsulated beliefs could then make the adult more aware of the teacher's deviant behavior in their memories. Ultimately, this could facilitate thinking of interventions to change this behavior.
\end{abstract}

\section{Keywords}

Public speaking anxiety, social anxiety disorder, cognitive model, etiological model, imagery rescripting. 


\section{Introduction}

Performance anxiety is defined as the fear concerning performing for an audience, including giving a public speech, a music performance or presentations in classes or meetings (Bögels et al., 2010). It is a subtype of social anxiety disorder (SAD) which constitutes anxiety for general social situations (APA, 2000). Although performance anxiety concerns non-general situations, it shares the same core cognitive concern about being scrutinised and judged negatively (Bögels et al., 2010). However, in comparison to SAD, performance anxiety shows a lower genetic component and a stronger psychophysiological panic-like response to performance situations (Blöte, Kint, Miers \& Westenberg, 2009). Moreover, Bögels et al. (2010) argue that performance anxiety has a later onset, can be relieved by $\beta$-blockers and has no correlation with personality characteristics such as shyness and behavioral inhibition. Rather, traumatic experiences or panic are important in the development of performance anxiety (Bögels et al., 2010). These findings are not directly related to cognitive and etiological factors underlying performance anxiety. Therefore, it is interesting to look into the traumatic experiences and study which factors could be important in contributing to performance anxiety specifically.

\section{Imagery}

In cognitive theory, one of the discussed characteristics of SAD is the image or visualization of a catastrophic scenario (Clark \& Beck, 2010). While these images are unpleasant and dominated by the observer perspective, they generate and maintain anxiety (Hackmann, Surawy \& Clark, 1998). Anxious individuals rely on them with regard as to how they might appear to others. Hackmann, Clark and McManus (2000) show these images are recurrent and associated with memories of 'traumatic' experiences. Memorised events could in this respect vary from being bullied at school to performing poorly in a meeting (Wild \& Clark, 2011). That is, there can be all sorts of memories which have a pictorial component and can be related to pathogenic early developed beliefs or schemas (Arntz \& Weertman, 1999). With regard to performance anxiety, Engelhard et al. (2012) argue that intrusive cognitive activity (thoughts and images) related to potential future catastrophe characterise this anxiety. They consider the relevant role of imagery based on literature on its role in SAD (Hackmann et al., 1998; Wild, Hackmann \& Clark, 2007). The imagery is related to thoughts concerning performing badly and being negatively evaluated. Engelhard et al. (2012) argue they could manifest as vivid, detailed and distressing flashforwards, in which future feared situations are imagined and visualised. Imagined future catastrophes experienced as intrusive images may fuel distress and avoidance behavior and are therefore considered to both decrease performance by distraction as well as maintain anxiety symptoms. 
Images about future catastrophe as described by Engelhard et al. (2012) are related to the experience of high negative affect, referred to as the 'hot cognition'. Contrary to the so called 'cold cognition', which is experienced more rationally and affect free, access to the 'hot cognition' can lead to more profound change in decreasing the negative appraisal of the image (Butler, Fennell \& Hackmann, 2008; Safran \& Greenberg, 1982). These concepts are confirmed by Holmes and Mathews (2010) in their review of imagery in emotional disorders in general, of which SAD is an example. They conclude imagery functions as an 'amplifier' for emotion compared to verbal representation of specific events. Taken together, studies on imagery in SAD demonstrate treatment could better target imagery than verbal cognitions (Holmes \& Mathews, 2010) and images are associated with memories of 'traumatic' experiences (Hackmann et al., 2000). With regard to imagery in performance anxiety, former research did not study memories whereas there are some results in the study on flashforwards (Engelhard et al., 2012).

\section{Imagery rescripting}

Based on the results concerning the role of imagery, research started focussing on changing the frequency and/or content of images rather than changing verbal cognitions (Arntz \& Weertman, 1999; Hackmann et al., 1998; Holmes \& Mathews, 2010). These are referred to as experiential methods in which a change of images is induced by using emotional experience rather than controlled thinking or behavior (Arntz \& Weertman, 1999). One of these methods is Imagery Rescripting (ImRs). The aim of ImRs is to adapt traumatic or anxiety provoking experiences by focusing on new adaptive meanings and by reducing the scope of the old experiences. In order to achieve this, different perspectives and related feelings and needs are experienced in the imagined 'traumatic' situation. An ImRs session consists of three phases. In the first phase it is asked to relive an anxiety provoking childhood memory as clear as possible. Second, the therapist asks to imagine the scene as an adult bystander and asks for upcoming thoughts and feelings resulting in an intervention that improves the situation for the child. Finally, in the third phase the client is asked to experience the situation as a child again and reflect on the interventions. In this phase it is also possible to intervene again (Arntz \&Weertman, 1999). Ultimately, it is important the client develops the belief that the early experience was an exception rather than the rule, thus changing dysfunctional anxious beliefs (Arntz \& Weertman, 1999; Hackmann, 2011).

With respect to the effectiveness of ImRs, Arntz and Weertman (1999) argue the technique is helpful in the treatment of chronic psychopathology with early origins. ImRs therefore does not exclusively suit one specific disorder (Arntz \& Jacob, 2012). Recent research in 
various mental disorders demonstrates promising results of ImRs, for instance in posttraumatic stress disorder (PTSD) (Grunert, Weis, Smucker \& Christianson, 2007; Arntz, Sofi \& Breukelen, 2013), depression (Brewin et al., 2009; Wheatley, Brewin, Patel \& Hackmann, 2007, Wheatley \& Hackmann, 2011), eating disorders (Tatham, 2011), medical patients experiencing intrusive memories (Whitaker, Brewin \& Watson, 2010) and personality disorders (Arntz, 2011; Napel-Schutz, Abma, Bamelis \& Arntz, 2011). With respect to ImRs in $S A D$, it is demonstrated that memory and image distress significantly improves whereas social anxiety and fear of negative evaluation decrease (Nilsson, Lundh \& Viborg, 2012; Wild et al., 2007; Wild, Hackmann \& Clark, 2008). Lee \& Kwon (2013) extended these results by showing ImRs could even be implemented as a stand-alone intervention for SAD.

\section{Etiology}

With regard to memories of socially anxious individuals, external factors could influence the likelihood of developing an anxiety when unpleasant or traumatic events have occurred. Rapee and Spence (2004) address these factors in their model of development of SAD. They include parent influences, peer influences and actual aversive social outcomes and negative life events. From their point of view, individuals have their own, mostly genetically mediated set point which reflects an individual's level of social anxiety. This set point could be altered by the aforementioned environmental influences in a degree dependent of their timing, impact or chronicity. An individual could for instance have a high genetic set point toward social anxiety, and as a consequence show fear for critical evaluation and have a low self esteem. Dependent of its timing, for instance the age of young adolescence, a negative speaking experience could negatively alter this set point and contribute to the development of anxiety. Alternatively, a group of supportive peers could encourage giving presentations and contribute to a lower level of anxiety. Aversive social outcomes and negative life events themselves contribute to an increase of the set point level of social anxiety (Rapee \& Spence, 2004).

\section{Present study}

The present study has an explorative character, in which it is assumed that individuals' current public speaking performance anxiety is associated with their reconstructed memories. From the data obtained by imagery rescripting on fourteen young adults with public speaking anxiety, results of the imagery interview adapted from Hackmann et al. (2000) contains the reconstructed 'traumatic' memory and will therefore be used for qualitative analysis. Overarching themes linked to etiology which are found across the data will be discussed on their contribution to the current anxiety. This paper will conclude 
with a discussion in which findings are translated into directions for altering the existing models and treatment on SAD for a group with public speaking performance anxiety.

\section{Material and methods}

Fourteen participants were enrolled in this study. They ranged in age from 18 to $31(\mathrm{M}=$ 22.64 years, $S D=4.22$ years). Only one participant was male although both sexes could have signed up for the study. The majority of the participants were students of whom two had recently graduated. They were recruited by announcements at different information channels connected with Maastricht University, for instance via flyers at the faculty of Health, Medicine and Life Sciences, via the digital learning environment EleUM and advertisements on social media. In the recruitment text they were asked to participate in a pilot studying a new intervention for public speaking anxiety. It was well communicated that no actual speech was expected from them, which could have lowered the threshold to participate. All individuals that signed up for the study received the screening questionnaire PRCS via e-mail to confirm public speaking anxiety (Personal Report of Confidence as a Speaker; Paul, 1966). Those with a score of 16 or higher were invited to actually participate in the study. This cut-off score was adapted from Paul (1966) and caused several individuals to be excluded from participating. Participation was rewarded by offering a 12.50 euro voucher or 2.5 credits for psychology students. All participants signed for informed consent.

All recorded interviews were transcribed by typing them out verbatim. The data set was analysed by thematic analysis as described by Braun and Clarke (2006). It was decided to conduct an analysis that would lead to a thematic description of the entire data set used in this study; the memory described in the imagery interview.

\section{Results}

Explicitly negative descriptions of deviant normative behavior emerged frequently from the data. These held behavior performed by the teacher or another authority figure. This is contrary to the behavior that participants reported to expect from them, for instance creating a safe environment, providing constructive feedback and giving support. 
Heel lullig hoe hij..hoe hij reageert sowieso.. heel kinderachtig.."

"Ging hij op elke zin wat ik had gezegd had hij wel kritiek. Hij ging met mijn medeklasgenootjes mopjes en grapjes maken terwijl ik ervoor stond van eh ja..hier ben ik."

"Ik vind achteraf gezien dat de docent heel verkeerd gehandeld heeft. Echt heel verkeerd want door het gedrag versterkte dat ook weer de reactie van de klasgenoten. En hij heeft niet echt een veilige omgeving gecreëerd en ook de manier van grapjes maken vind ik dat hij de humor moet ook, dat hij dat ook moet aanpassen, want ja bij mij komt dat gewoon heel verkeerd over"

"Ik ben een student en hij is degene waar ik een stageopdracht voor mag doen. Zo voelt het, hij helpt mij met iets, hij helpt mij met afstuderen. Ik moet opdrachten voor hem vervullen en ik moet het goed doen en ik moet aan zijn verwachtingen voldoen. Maar zijn verwachtingen en zijn eisen liggen zo hoog dat ze eigenlijk onhaalbaar zijn.”

"Terwijl ik weg loop ziet de juf mij aan en doet niks. Loopt gewoon aan. En ze vraagt gewoon niet eens wat er was. Dat interesseert ze niet. Niemand heeft ooit aan mij gevraagd: hoe voel jij je? of wat.. wat..weet je.. (huilt). Kunnen we iets voor je doen? Of wil je dat we iets voor je doen? Niemand! (huilt)"
"Very lousy how he reacted, and very childish anyway."

"He criticised every word I said. He made fun with my fellow students while I was standing in front of them like, yes.. I am still here."

"Now I look back to it, I think the teacher acted very incorrectly. Really very incorrectly since his behavior enhanced the response of the peers in the classroom. And he didn't create a safe environment and also his way of joking..he should adapt his that, since it comes across very wrong to me."
"I'm a student and he is the one for who I am allowed to do an internship assignment. That's how it feels, he helps me with something, he helps me graduating. I have to do assignments for him and I have to do well and meet his expectations. However, his expectations and his demands are so high that they are actually unfeasible."

"When I walk away, the teacher watches me and does nothing. She just walks away. And she didn't even ask what happened. That didn't interest her. Nobody ever asked me how I feel you know (starts crying). Can we do something for you? Or do you want us to do something? Nobody! (cries on)."

Overall, the themes revealed from the flashback interviews offer qualitative insights on different aspects of performance anxiety. With regard to etiological factors to SAD, negative influence of teacher behavior was reported.

\section{Discussion/Conclusion}

Within the current ImRs procedure, clients are requested to think of interventions to change the early experience from an adult perspective (Arntz \& Weertman, 1999). Therefore, this stage actually requests clients to do some cognitive work and imagery at 
the same time. During this phase, influencing factors relevant to the anxiety could be rescripted when the client thinks this would help the child or young adolescent in that situation. The current ImRs procedure assumes client $X$ in its current state could think as an adult, competent, wise version of the child X (Arntz \& Weertman, 1999; Lee \& Kwon, 2013). For the participants in their young adulthood however, it could be difficult to think of interventions to deal with a teacher for instance. That is, they could still be vulnerable to criticism and still unable to appraise a particular behavior towards the normative behavior that is expected. This is considered based on the relatively short time span between the age with which young adults are involved within ImRs and the age in the described memory.

In order to facilitate the second phase of the ImRs procedure, literature suggests to combine cognitive challenging with the imagery rescripting. This is referred to as cognitive restructuring and is studied by Lee and Kwon (2013) and Wild et al. (2008) in which they examined the validity of the participants' encapsulated belief by challenging negative thoughts and assumptions. That is, the cognition about the self on which thoughts and behavior are based in specific situations. They argue cognitive restructuring contributes to the effect of ImRs by defining the new perspective more clearly and as a consequence preparing the client to incorporate related interventions in the second ImRs phase. They indicate an enhancement of the effect of ImRs, based on a comparison of their results with the results of a study conducted by Nilsson et al. (2012) who did not specifically intervene on cognitions. The treatment effects on change of the encapsulated belief in the latter study were shown to continue less long.

Based on the present study results it is suggested to focus more on teacher behavior when conducting ImRs on young adults with performance anxiety. The results indicate participants place blame on authority figures like teachers and assessors which are expected to set an example. It could be interesting to study the perception of this influencing factor further in depth. For instance, what are specific expectations on teacher behavior based on and how did these develop? In educating on the interpretation of the exemplary role of the teacher, parents might be important. When studying this topic on actual behavior, it is further suggested to increase the validity by including objective observers, as in prior research on teacher treatment (Babad, 1990; Blöte, 1995).

Finally, in concordance with Lee and Kwon (2013) regarding SAD, it is suggested to examine how cognitive restructuring would contribute to the effect of ImRs regarding performance anxiety. From the present study's perspective, this would in particular be effective when addressing the additional role of the teacher in the development of performance anxiety and when treating young adults. That is, they are considered to be still vulnerable to this 
influence since their memories occurred at the age of adolescence instead of childhood. Furthermore, Voncken, Alden and Bögels (2006) suggest that socially anxious young adults are aware of the negative social effect of engaging in safety behaviors. This implies it is useful to discuss negative interpersonal consequences of safety behavior. However, they also found their participants still believed acknowledging their anxiety would produce negative responses. This could be an additional reason to let the actual imagery rescripting be preceded by a cognitive session in which these beliefs will be challenged. In conclusion, for young adults with public speaking performance anxiety it is considered to precede the imagery rescripting session with a cognitive session. With this, encapsulated beliefs concerning relevant anxiety contributing peer and teacher behavior could be challenged. Although more research is required to study teacher and other influences in relation to public speaking performance anxiety, this study provides directions for effective imagery rescripting in young adults with this anxiety.

\section{Role of the student}

Karlijn Hermans was an undergraduate student in Health Sciences working under the supervision of dr. Marisol Voncken when the research in this report was performed. The supervisor proposed the topic of this study since there was a project running on public performance anxiety. Karlijn supported the execution of a qualitative analysis of the raw data a master's student already collected and shared in return. Karlijn and the master's student both transcribed and analyzed another part of the data. The processing of the results as well as formulation of the conclusions and the writing were done by Karlijn.

\section{Acknowledgments}

Special thanks are given to I. Nijssen, MA for conducting the imagery rescripting and sharing the raw data. I would also like to express my very great appreciation to $d r . M$. Voncken for her constructive feedback and inspiring suggestions during the research and writing process.

\section{References}

1. American Psychiatric Association (2000). Diagnostic and Statistical manual of Mental disorders, Fourth Edition, Text Revision, (DSM-IV-TR). Washington DC: APA.

2. Arntz, A. (2011). Imagery Rescripting for Personality Disorders. Cognitive and Behavioral Practice, 18, 466-481.

3. Arntz, A., \& Jacob, G. (2012). Schematherapie. Een praktische inleiding. Amsterdam: Uitgeverij Nieuwezijds.

4. Arntz, A., Sofi, D., \& Breukelen, G. van (2013). Imagery Rescripting as Treatment for Complicated PTSD in Refugees: A Multiple Baseline Case Series Study. Behavior Research and Therapy, 51, 274-283.

5. Arntz, A., \& Weertman, A. (1999). Treatment of Childhood Memories: Theory and Practice. Behavior Research and Therapy, 37, 715-740. 
6. Babad, E. (1990). Measuring and Changing Teachers Differential Behavior as Perceived by Students and Teachers. Journal of Educational Psychology, 82, 683-690.

7. Blöte, A. W. (1995). Students' Self-Concept in Relation to Perceived Differential Teacher Treatment. Learning and Instruction, 5, 221-236.

8. Blöte, A. W., Kint, M. J. W., Miers, A. C., \& Westenberg, P. M. (2009). The Relation Between Public Speaking Anxiety and Social Anxiety: A Review. Journal of Anxiety Disorders, 23, 305-313.

9. Bögels, S. M., Alden, L., Beidel, D. C., Clark, L. A., Pine, D. S., Stein, M. B., et al. (2010). Review: Social Anxiety Disorder: Questions and Answers for the DSM-V. Depression and Anxiety, 27, 168-189.

10. Braun, V., \& Clarke, V. (2006). Using Thematic Analysis in Psychology. Qualitative Research in Psychology, 3 (2), 77-101.

11. Brewin, C. R., Wheatley, J., Patel T., Fearon, P., Hackmann A., Wells, A., Fisher P., \& Myers, S. (2009). Imagery Rescripting as a Brief Stand-Alone Treatment for Depressed Patients with Intrusive Memories. Behavior Research and Therapy, 47, 569-576.

12. Butler, M., Fennell, M., \& Hackmann, A. (2008). Cognitive behavioral therapy for anxiety disorders. New York: Guilford Press.

13. Clark, D. A., \& Beck, A. T. (2010). Cognitive therapy of anxiety disorders. Science and practice. New York: Guilford Press.

14. Engelhard, I. M., Sijbrandij, M., Hout, M. A. van den, Rutherford, N. M., Rahim, H. F., \& Kocak, F. (2012). Choking Under Pressure: Degrading Flashforwards Related To Performance Anxiety. Journal of Experimental Psychology, 32 (2), 158-167.

15. Grunert, B. K., Weis, J. M., Smucker, M. R., \& Christianson, H. (2007). Imagery Rescripting and Reprocessing Therapy after Failed Prolonged Imaginal Exposure for Posttraumatic Stress Disorder Following Industrial Injury. Journal of Behavior Therapy and Experimental Psychiatry, 38, 317-328.

16. Hackmann, A. (2011). Imagery Rescripting in Posttraumatic Stress Disorder. Cognitive and Behavioral Practice, $18,424-432$

17. Hackmann, A., Clark, D. M., \& McManus, F. (2000). Recurrent Images and Early Memories in Social Phobia. Behavior Research and Therapy, 38, 601-610.

18. Hackmann, A., Surawy, C., \& Clark, D. M. (1998). Seeing Yourself Through Others' Eyes: A Study of Spontaneously Occurring Images in Social Phobia. Behavioral and Cognitive Psychotherapy, 26, 3-12.

19. Holmes, E. A., \& Mathews, A. (2010). Mental Imagery in Emotion and Emotional Disorders. Clinical Psychology Review, 30, 349-362.

20. Lee, S. W., \& Kwon, J-H. (2013).The Efficacy of Imagery Rescripting (IR) for Social Phobia: A Randomized Controlled Trial. Journal of Behavior Therapy and Experimental Psychiatry, 44, 351-360.

21. Napel-Schutz, M. C. ten, Abma, T. A., Bamelis, L. \& Arntz, A. (2011). Personality Disorder Patients' Perspectives of Imagery Within Schema Therapy: A Qualitative Study of Patients' Experiences. Cognitive and Behavioral Practice, 18, 482-490.

22. Nilsson, J-E., Lundh, L-G., \& Viborg, G. (2012). Imagery Rescripting of Early Memories in Social Anxiety Disorder: An Experimental Study. Behavior Research and Therapy, 50, 387-392.

23. Paul, G. L. (1966). Insight vs. desensitization in psychotherapy. Standford, CA: Standford University Press.

24. Rapee, R. M., \& Spence, S. H. (2004). The Etiology of Social Phobia: Empirical Evidence and an Initial Model. Clinical Psychology Review, 24, 737-767.

25. Safran, J. D., \& Greenberg, L. S. (1982). Eliciting “Hot Cognitions” in Cognitive Behavior Therapy: Rationale and Procedural Guidelines. Canadian Psychology, 23 (2), 83-87.

26. Tatham, M. (2011). The Role of Imagery-Based Techniques in Cognitive- Behavioral Therapy for Adults With Eating Disorders. Clinical Psychology Review, 31, 1101-1109. 
27. Voncken, M.J., Alden, L. E., \& Bögels, S.M. (2006). Hiding Anxiety Versus Acknowledgment of Anxiety in Social Interaction: Relationship with Social Anxiety. Behavior Research and Therapy, 44, 1673-1679.

28. Wheatley, J., Brewin, C. R., Patel, T., \& Hackmann, A. (2007). "I'll Believe It When I Can See It": Imagery Rescripting of Intrusive Sensory Memories in Depression. Journal of Behavior Therapy and Experimental Psychiatry, 38, 371-385.

29. Wheatley, J., \& Hackmann, A. (2011). Using Imagery Rescripting to Treat Major Depression: Theory and Practice. Cognitive and Behavioral Practice, 18, 444-453.

30. Whitaker, K. L., Brewin, C. R., \& Watson, M. (2010). Imagery Rescripting for Psychological Disorder Following Cancer: A Case Study. British Journal of Health Psychology, 15, 41-50.

31. Wild, J., \& Clark, D.M. (2011). Imagery Rescripting of Early Traumatic Memories in Social Phobia. Cognitive and Behavioral Practice, 18, 433-443.

32. Wild, J., Hackmann, A., \& Clark, D. M. (2007). When the Present Visits the Past: Updating Traumatic Memories in Social Phobia. Journal of Behavior Therapy and Experimental Psychiatry, 38, 386-401.

33. Wild, J., Hackmann, A., \& Clark, D. M. (2008). Rescripting Early Memories Linked to Negative Images in Social Phobia: A Pilot Study. Behavior Therapy, 39, 47-56. 